\title{
Performance of Boer and their Crossbreed Goats in Nepal - A Review
}

\section{S. Parajuli}

Lamjung Campus, Institute of Agriculture and Animal Science, Tribhuvan University, Nepal

Received: 5 Oct 2020; Received in revised form: 9 Nov 2020; Accepted: 15 Nov 2020; Available online: 17 Nov 2020

\begin{abstract}
There are about 10.25 million goats in Nepal. Most of these are local and adaptive to different ecological zones of Nepal. Despite of big goat population, performance in terms of daily gains were very low as compared to the Boer crossbreeds. The crossbreed Boer goat is a remarkable small-stock ruminant that possesses distinctive qualities enabling it to excel as an efficient production performer. The Boer goats had faster growth rates and were heavier than the indigenous breeds of goats from Nepal. The daily gain of Boer is 80-140 gm/day and Boer crossbreeds is 100-200 gm/day varying with different blood level of Boer crossbreeds. It is early maturing, reaching a mean maximum weight $\approx 62 \mathrm{~kg}$ at 3.5 years of age on natural pasture under extensive grazing conditions. Twinning percentage is about $40-50 \%$ in the crossbreeds. The indigenous goats of Nepal are subjected to crossbreeding with Boer goats in order to utilize the Boer goat breed as an alternate breed for production and reproduction performances. Boer milk is rich in fat followed by lactose and protein. Dressing percentage is about 56-60\% at the age of full teeth placement. They are resistant to various disease due to better performance of adrenal cortex and high cortisol production. Mortality rate is more for quadruplet and triplet kids. They are the best browsers and used as a controller in bush encroachment. Flexibility in acclimatization and other vital characteristics signified better performance of Boer and their crossbreeds in diverse country like Nepal.
\end{abstract}

Keywords-Nepal, Boer, crossbreeds, performance.

\section{INTRODUCTION}

Goat (Capra hircus), being the most common domestic animals reared, is the second most important meat animals after the buffalo meat in Nepal. Boer, Barberi, Jamunapari and Beetle are popular exotic breeds used for cross breeding to upgrade indigenous breeds like Khari, Terai, Sinhal etc.(Bhattarai et al., 2019).Low investment requirement attracts Nepalese farmer to get involved in goat farming, showing statistically $49.8 \%$ household rear goats with average holdings of 3.3/household (CBS, 2012).Sector of goat provides a strong sustenance in source of revenue of Nepalese farmers of hills and terai which constitute the higher share of land area and inhabitants of the country (Neupane et al., 2018). Figures regarding to goat population showed that there are more than 10.25 million heads of goats in the Nepal with the rise in goat population during 2001-2015 with $3.65 \%$ per year contributing about $20.1 \%$ to the total meat production in the country(Secretary \& Division, 2015).Due to low producing ability of indigenous goats as compared to the exotic breeds, this production does not meet the growing demand and fulfillment is accomplished by importing from foreign country, especially from India and China. To overcome this situation, full blooded Boer goat are crossed with local breeds or developing Nepalese pure Boer goat by upgrading(Sciences, 2017).

Accomplishment of very productive goats within a short period of time and to obtain superior stock from elsewhere, crossbreeding appears to be an easy technique (Belay et al., 2014). The result will bring up the hybrid vigor or heterosis and it is expected that crossbreed give rise to improved performance compared to both parents for instance production or reproductive traits(Nugroho et al., 2019). Refining genotype within breed, compared to crossbreeding, selection via adaptation and genetic gain is sustainable but is a time-consuming method with genetic gain/generation as low as $<5 \%$ (McDowell, 1972). Crossbreeding is taken as beneficial and decision of choice as crossbreeding goats can bring about their quick 
enhancement by improving their genetic performance (Mustefa et al., 2019).

Originated in South Africa, Boer goats are meat category goats introduced in many countries counting Nepal as a result of good resistance capacity, quick growth rate, heavier body weight, high prolificacy with average litter size almost two and high carcass quality (Lu, 2001). Owing to these important qualities, crossbreeding of indigenous breeds with Boer has been common in Nepal since it is a better method to get productive goats in short period of time(Sapkota et al., 2016).Boer of origin Eastern Cape of South Africa $\approx 60$ years ago, has been very adjacent to the perfect Boer to bred due to forethought of a no of Boer breeders, who stringently selected goats with a definitive breeding policy (Erasmus, 2000). Five phases of determination for performance testing of Boer started in 1970 under south African Mutton and Goat Performance and Progeny testing Scheme(N. H. Casey \& Van Niekerk, 1988).Ability to convey its superior phenotypic physiognomies to other breeds when used for crossbreeding is supplementary in Boer(Barry \& Godke, 1991).Boer was familiarized in Nepal from a private sector to advance growth performance of local goats subsidized by World bank, IFAD, AFSP etc. Goat research station; Bandipur, RARS (khajura), GDF (Budhitola) are the government-owned farms with nucleus herd of Boer goat in Nepal (Bhattarai et al., 2019).Indigenous goats are being collected at Lumle Agricultural Research Centre (LARC) since late 1980s from western hills aiming to evaluate their performance and explore the possibility of improvement of their genetic potential (Rasali \& Khanal, 2002).Boer become a potential genetic resource in crossbreeding programs for improving Nepalese local goat productivity.

\section{DISCUSSION}

\section{Boer as an exotic breed}

Infusion of European, Angora and Indian goat, Boer is a horned breed with lop ears and varietal color pattern with most common white body with red head and muscular frame. Goat is full-bodied with decent shape and roman nose comprising short, well fleshed good thigs and hind legs for good carcass features (Campbell, 1984). Being popular for its browsing skill with limited impact on grass cover, mature buck masses $100-135 \mathrm{~kg}$ and does between $90-100 \mathrm{~kg}$. With daily gains $200 \mathrm{~g}$ in feedlot, ovulation rate ranges from 1-4eggs/doe with average of 1.7 and kidding rate of $200 \%$. Male reaches puberty at about 6 months and females at 10-12 months and protracted breeding season making possible of 3 kids every 2 years (Bhattarai et al., 2017).Accountabilities for culling are a hollow forehead, slender mouth, folded ears, under-shot jaws, hollow back, weak pasterns, front $\mathrm{x}$-shaped legs, small testes, hooves turning in or out, elongated coarse and wooly hair covering, thick, big teats, and less than $25 \%$ pigmentation (N. H. Casey \& Van Niekerk, 1988). The Boer goats which are nowadays receiving quick acceptance in the industrialized (USA, New Zealand, Australia, Japan) and emerging (Sir Lanka, India) nations have reckless progress rate pre and post-weaning with an outstanding feed conversion ratio; 1:3.18-3.60(Feed \& Council, 1997) and truncated cholesterol content are already familiarized in Nepal by a private farmer Mahesh Basnet in 1999(Panday, 2008).

\section{Boer for crossbreeding}

Boer goat producing decent crossbreeds having hybrid potency with indigenous breeds are more resilient to diseases compared to native breeds and its crosses correspondingly convey this resistance (Panday, 2008). In the last few decades(1990s), Khari goats were tremendously crossed with Indian Jamunapari and Barberi goats for growing production with postulation but is now substituted with Boer either naturally or through artificial insemination with frozen semen through the foremost private goat impresarios due to various research directed by NARC, ARSs, DLS etc.(Bhattarai et al., 2019).With the intention of conveying the superior phenotypic characteristics of a breed to the F1 progeny, Boer fits finest due to accessibility of these outstanding phenotypic characters which can be envisioned in its crossbreed offspring(Barry \& Godke, 1991). The potentials of crossbreeding are adaptability, hardiness, better growth, early maturity, disease resistant, less kid mortality, better twinning percentage, improved milk production and lactation and many more.

\section{Performances of Boer and their crossbreeds}

\section{Adaptability and hardiness:}

Flexibility of farm animals in their capability to acclimatize to several climates and production schemes is an economically vital characteristics signified better by reproductive performance with reproductive life of 10 years(Campbell, 1984).Despite acclimatization being a slow procedure taking a year or extended, Boer characterizes itself as one of the robust amongst the small stock breeds having the capability to familiarize to almost any climate, from the hottest dry desert to the snowcovered mountains(Barry \& Godke, 1991).

With strong and sturdy legs, Boer can travel long distances along dense shrubbery lands and over rugged mountains for food and water and survive droughts without supplementary feed being the best of all goat breeds.Small 
dimensions, huge surface area to body weight, water conservation ability, restricted subcutaneous fat cover and the specific nature of their coats make Boer to adjust in hot than in cold environment (Shkolnik \& Choshniak, 1985). The behavioural attribute of goat to feed selectively smooths their ability to endure under strict tropical and semi-arid surroundings(N. H. Casey \& Van Niekerk, 1988). Ability to reside the latter environment with occasional management practices such as vaccination and medicating, the terms hardiness and adaptability are attached to this animal. Boer may finest be designated by the following quotation: "Certainly one of the most hardy of small-stock breeds on earth, with a great ability of adaptation; it is therefore found in such a wide variety of climates and grazing conditions"(Erasmus, 2000).

\section{Growth Performances:}

Heavier body weight and faster growing rate are the most notable among all superior traits.

Genetic parameters of development traits of kids are vital in enlightening their genetic makeup with respect to production and efficiency. In a research conducted in GRS Bandipur(NCRP, 2019), total no of 52 off-springs (23 male and 29 females) from 26 pure dams, the average weight at birth of pure Boer kid was $3.79 \mathrm{~kg}$ with average weaning weight 18.59 and eight month weight of $28.34 \mathrm{~kg}$. The average yearling weight of the Boer was found 45.74 $\mathrm{kg}$.

The average daily gain of the pure Boer kids in one year was found to be $114.93 \mathrm{gm} /$ day which is comparatively more than that of Khari goats.

Table.1: Growth Performances of pure Boer, 2075/76(NCRP, 2019)

\begin{tabular}{lllll}
\hline \multicolumn{1}{c}{ Age } & \multicolumn{3}{c}{ Male } & \multicolumn{2}{c}{ Female } \\
& Weight(kg) & Wt. gain(gm/day) & Weight(kg) & Wt. gain(gm/day) \\
Birth & $4.02 \pm 0.16$ & & $3.62 \pm 0.12$ & \\
Weaning & $18.79 \pm 0.78$ & 123.07 & $18.44 \pm 0.41$ & 123.36 \\
8 months & $32.56 \pm 5.42$ & 118.92 & $24.12 \pm 5.13$ & 85.50 \\
12 months & $50.80 \pm 6.25$ & 128.17 & $40.67 \pm 5.77$ & 101.37 \\
\hline
\end{tabular}

Boer goats are renowned having faster growing rate compared to others. Weaning methods, stress and compensatory growth affects the growth rate $(\mathrm{Lu} \&$ Potchoiba, 1988).Illustration can be taken that growth rate of Boer kids can be abridged by adaptation in the internment alone (N. H. Casey \& Van Niekerk, 1988). Incessant genetic selection improvement, feeding and supervision may subsidize to even a faster growing rate in Boer goats as well as their crosses (Lu, 2001).
Evaluation of different blood levels of the Boer goat in different ecological region of Nepal ongoing. $2.38 \mathrm{~kg}$ and $2.64 \mathrm{~kg}$ the average weight at birth, $15.87 \mathrm{~kg}$ and $16.63 \mathrm{~kg}$ the average weaning weight, $26.88 \mathrm{~kg}$ and $27.24 \mathrm{~kg}$ the average eight months weight and $39.97 \mathrm{~kg}$ and $41.01 \mathrm{~kg}$ the average annual weight was of $50 \%$ and $75 \%$ Boer goats found in the research of Boer X Khari goats.

Table.2: Growth Performances of Boer Crossbreed 50\%, 2075/76(NCRP, 2019)

\begin{tabular}{lllll}
\hline \multicolumn{1}{c}{ Age } & \multicolumn{3}{c}{ Male } & \multicolumn{2}{c}{ Female } \\
& Weight $(\mathrm{kg})$ & Wt. gain(gm/day) & Weight $(\mathrm{kg})$ & Wt. gain $(\mathrm{gm} /$ day $)$ \\
Birth & $2.72 \pm 0.62$ & & $2.06 \pm 0.72$ & \\
Weaning & $17.42 \pm 2.94$ & 122.50 & $14.34 \pm 2.18$ & 102.37 \\
$\mathbf{8}$ months & $28.28 \pm 2.33$ & 106.55 & $25.49 \pm 2.90$ & 97.66 \\
$\mathbf{1 2}$ months & $41.08 \pm 1.93$ & 106.61 & $38.88 \pm 1.65$ & 102.32 \\
\hline
\end{tabular}


International Journal of Environment, Agriculture and Biotechnology, 5(6)

Nov-Dec, 2020 / Available: https://ijeab.com/

Table.3: Growth Performances of Boer Crossbreed 75\%,2075/76(NCRP, 2019)

\begin{tabular}{lllll}
\hline \multicolumn{1}{c}{ Age } & \multicolumn{3}{c}{ Male } & \multicolumn{2}{c}{ Female } \\
& Weight $(\mathrm{kg})$ & Wt. gain(gm/day) & Weight $(\mathrm{kg})$ & Wt. gain(gm/day) \\
Birth & $2.92 \pm 0.26$ & & $2.36 \pm 0.27$ & \\
Weaning & $16.54 \pm 2.34$ & 113.50 & $16.73 \pm 2.31$ & 119.75 \\
$\mathbf{8}$ months & $27.73 \pm 2.42$ & 103.37 & $26.75 \pm 2.76$ & 101.62 \\
12 months & $43.69 \pm 2.59$ & 111.69 & $38.33 \pm 2.88$ & 98.54 \\
\hline
\end{tabular}

Average daily weight increase in $5^{\text {th }}$ and $6^{\text {th }}$ month of age was low which might be due to the weaning stress as weaning was done in the $4^{\text {th }}$ month of age.
Rendering to the study in Sharabeshi of Bakrang, Gorkha, Boer crossbreeds (25\% blood level) had achieved better performance in comparison to local Khari goat.

Table.4: Mean body weight and body weight gain Boer crossbreed (25\% blood level) up to 12 months age at Sharabeshi, Gorkha in 2070/71, (NCRP, 2014)

\begin{tabular}{lllll}
\hline \multicolumn{1}{c}{ Age } & \multicolumn{2}{c}{ Male } & Female \\
& Weight(kg) & Wt. gain(gm/day) & Weight $(\mathrm{kg})$ & Wt. gain(gm/day) \\
Birth & 2.76 & & 2.68 & \\
4 months & 13.65 & 80.00 & 12.50 & 66.67 \\
$\mathbf{8}$ months & 22.20 & 76.67 & 20.30 & 68.33 \\
12 months & 31.50 & 76.67 & 28.00 & 63.33 \\
\hline
\end{tabular}

Rendering to the study in Pekhuthana, Syangja, Boer crossbreeds had performed better performances in comparison to local Khari goat.

Table.5:Mean body weight and body weight gain Boer crossbreed (25\% blood level) up to 12 months age at Pekhuthana, Syangja in 2073/74,(NCRP, 2017)

\begin{tabular}{lllll}
\hline \multicolumn{1}{c}{ Age } & \multicolumn{2}{c}{ Male } & \multicolumn{2}{c}{ Female } \\
& Weight(kg) & Wt. gain(gm/day) & Weight(kg) & Wt. gain(gm/day) \\
Birth & 2.76 & & 2.67 & \\
Weaning & 13.42 & 88.83 & 12.68 & 83.41 \\
8 months & 21.89 & 79.71 & 19.12 & 68.54 \\
12 months & 30.47 & 75.91 & 29.22 & 72.74 \\
\hline
\end{tabular}

Table.6: Mean body weight and weight gain of Boer crossbreed (50\% and $75 \%$ blood level) up to five months of age at Pekhuthana, Syangja in 2075/76 (NCRP, 2019)

\begin{tabular}{|c|c|c|c|c|c|c|c|c|}
\hline \multirow[t]{2}{*}{ Age } & \multicolumn{2}{|c|}{$\begin{array}{l}\text { Wt. of Boer }(50 \%) \\
\text { kg }\end{array}$} & \multicolumn{2}{|c|}{$\begin{array}{l}\text { Wt. gain of Boer } \\
(50 \%) \text { gm/day }\end{array}$} & \multicolumn{2}{|c|}{$\begin{array}{l}\text { Wt. of Boer (75\%) } \\
\mathrm{kg}\end{array}$} & \multicolumn{2}{|c|}{$\begin{array}{l}\text { Wt. gain of Boer } \\
(75 \%) \text { gm/day }\end{array}$} \\
\hline & Male & Female & Male & Female & Male & Female & Male & Female \\
\hline Birth & 2.93 & 2.75 & & & 3.26 & 2.50 & & \\
\hline $1^{\text {st }}$ month & 7.26 & 6.24 & 142.49 & 114.64 & 7.92 & 7.70 & 153.34 & 171.06 \\
\hline $2^{\text {nd }}$ month & 12.42 & 10.87 & 202.52 & 152.25 & 16.65 & 17.96 & 287.15 & 337.41 \\
\hline $3^{\text {rd }}$ month & 15.93 & 14.17 & 82.45 & 108.49 & 19.25 & 19.36 & 85.35 & 45.93 \\
\hline $4^{\text {th }}$ month & 20.38 & 18.22 & 146.47 & 133.08 & 26.84 & 24.79 & 249.53 & 178.65 \\
\hline $5^{\text {th }}$ month & 24.86 & 21.53 & 147.19 & 108.85 & 29.44 & 27.01 & 85.35 & 72.69 \\
\hline
\end{tabular}


The birth weight of Boer X Khari cross kids is inferior than the birth weight of Boer kids but bear a resemblance to the birth weight of Khari kids (Rasali \& Khanal, 2002). Weightier birth mass of male is reinforced by findings ofNeopane \& Sainju, 1995 and Upreti \& Mahato, 1995. The weaning weight of Boer X Khari cross kids differs by gender which is alike with Boer X Central highland cross kids (Deribe \& Taye, 2013), though inferior than pure Boer weaning kids (Lu \& Potchoiba, 1988).As per this study, weight gain was highest in Boer $50 \%$. Kids born in monsoon were significantly weightier at birth due to availability of green forages and improved nutritional status, it did not affect their body weights up to 12 months of age as season of birth had zero significance on the body weight(Rasali \& Khanal, 2002). Influences of genetics, nutrition, health and disease, breeding age and method of management system can vary the weight measurements (Lu, 2001).

\section{Reproduction Performance:}

Most important criterion relating to adaptation is reproductive performance. Maximum fertility appeared to attained at the relatively early age of 3.5 years. Crossbreed Boer is early maturing at the age of 1.5 years (Erasmus, 2000). Low post-natal mortality along with high rate of reproduction are the important requirements for meat producing animals; as it is best fit for goat than other domestic ruminants due to higher average litter sizes (Shelton, 1978).The reproductive performance of the Boer goat was documented to access the reproductive performance of pure Boer goat in GRS, Bandipur.

Table.7: Reproductive performance of pure Boer goat 2075/76 (NCRP, 2019)

\begin{tabular}{lll}
\hline Reproductive parameters & Days & No of Observations \\
Age at first service & $270-400$ & 21 \\
Age at first kidding & $410-510$ & 15 \\
Litter size at birth & $1.73(1-3)$ & 15 \\
Post-Partum Estrus & $110-170$ & 15 \\
Kidding interval & $210-300$ & 15 \\
\hline
\end{tabular}

Boer X Khari goats are also subjected to access the reproductive performances $(75 \%$ Boer cross doe and $50 \%$ Boer cross doe with Khari breeds).

Table.8: Reproductive performances of Boer X Khari crosses(F1) and Boer X Boer F1(F2) 2075/76(NCRP, 2019)

\begin{tabular}{lll}
\hline Reproductive parameters & F1(Boer 50\% doe) & F1(Boer 75\% doe) \\
Age at first service & $220-270$ & $210-290$ \\
Age at first kidding & $360-380$ & $300-400$ \\
Litter size at birth & $1.54(1-3)$ & $1.55(1-3)$ \\
Post-Partum Estrus & $65-112$ & $70-125$ \\
Kidding interval & $240-360$ & $220-380$
\end{tabular}

Conception rate and kidding pattern of the Boer goats at 75\% blood level and 50\% blood level are similar but lesser in Boer cross $87.5 \%$ doe.

Table.9: Conception rate and kidding pattern of Boer crosses at GRS 2075/76(NCRP, 2019)

\begin{tabular}{lllll}
\hline Parameters & & \multicolumn{2}{l}{ Boer cross Doe blood Level } \\
Conception rate & & $\mathbf{8 7 . 5 \%}$ & $\mathbf{7 5 \%}$ & $\mathbf{5 0 \%}$ \\
& Single & 66.66 & 93.60 & 96.08 \\
\multirow{2}{*}{ Kidding type } & Twin & 50.00 & 47.22 & 48.61 \\
& Triplet & 50.00 & 50.00 & 48.61 \\
Kidding rate/ doe & & 0.00 & 2.78 & 2.78 \\
\hline
\end{tabular}


Performance testing scheme shows the following reproduction performances (Campbell, 1984).

Table.10: Reproduction Performance of Pure Boer Breed(Campbell, 1984) in South Africa

\begin{tabular}{ll}
\hline Females kidded & 98 \\
Singles Born & 24 \\
Twins Born & 116 \\
Triplets Born & 45 \\
Quadruplets Born & 4 \\
No of kids per parturition & 1.93 \\
Singles weaned $*$ & 26 \\
Twins weaned & 112 \\
Triplets weaned & 4 \\
\cline { 2 - 2 } : & kids were born as twins or triplets but reared as singles $\}$
\end{tabular}

This suggests that with average litter size nearly equal to 2 , Boer produced twinning kids and triplets up to $60 \%$ and $10-15 \%$ respectively. The birth type of Boer goat vary from $15-24.5 \%$ single, $59.2-67.5 \%$ twins and $15.3-16.3 \%$ triplets (Greyling, 2000).

Weak appearance of does leads to abortions which plagued Boer in some areas were described due to undernutrition. Experimental investigation byCoetzer \& Van Niekerk,

Table.11: Estrous cycle of Boer (Barry \& Godke, 1991)

\begin{tabular}{ll}
\hline Length of estrus cycle & 20.7 days \\
Does with cycles LT or EQ to 13 days & $16.6 \%$ \\
Does with cycles GT or EQ to 25 days & $10.2 \%$ \\
Mean length of Estrus & 37.4 hours \\
\hline
\end{tabular}

Boer goat is a moderately seasonal breeder but complete anestrus does not occur in the breed(Van der Westhuysen, 1979), stirred by shortening daylight with ultimate sexual activity in April-May and least in October-January (Greyling \& Van Niekerk, 1986).

Table.12: Gestation Period of Boer (Barry \& Godke, 1991)

\begin{tabular}{ll}
\hline Mean Gestation Period & $\mathbf{1 4 8 . 2}$ days \\
Does with singles & 149.1 days \\
Does with twins & 147.8 days \\
Does with triplets & 146.8 days \\
$\quad$ Postpartum anestrous period & \\
Kidding in kidding season (sept-oct) & 37.3 days \\
Kidding in off season (mar-apr) & 59.9 days \\
First cyclic activity post-kidding & 20 days \\
Kidding to pregnancy (no breeding season) & 62 days \\
\hline
\end{tabular}

Estrus cycle are longer than 21 days during the period of least sexual activity. 


\section{Milk Production Performance:}

Parental physiognomies of the goat doe are reliant on the figure of kids weaned per doe kidded. Milk production of the doe throughout the preweaning phase is one of the chief status to permit high growth rates of kids, particularly in does having multiple births as the fact that high fecundity is one of the Boer's sturdiest qualities(Erasmus, 2000). Foeto-placental units and placental weight determines the degree of mammary

Table.13: Mean milk production and milk composition during 12 weeks of lactation of Boer goat does (Raats et al., 1983)

\begin{tabular}{lllllll}
\hline Age of & Litter & Milk Yield & \multicolumn{3}{c}{ Milk composition } \\
Does(teeth) & Size & (kg/day) & \% Protein & \% Fat & \% T. S & \% Lactose \\
2 & Single & 1.5 & 4.5 & 7.5 & 17.3 & 4.7 \\
2 & Twins & 1.9 & 4.4 & 7.0 & 16.8 & 4.7 \\
2 & Triplets & 2.3 & 4.2 & 6.4 & 15.8 & 4.6 \\
4 & Singles & 1.8 & 4.5 & 7.7 & 17.9 & 4.9 \\
4 & Twins & 1.9 & 4.3 & 7.4 & 17.1 & 4.8 \\
6 & Singles & 2.1 & 4.4 & 9.4 & 19.2 & 4.7 \\
6 & Twins & 2.2 & 4.1 & 8.1 & 17.4 & 4.7 \\
6 & Triplets & 2.5 & 3.9 & 7.6 & 17.0 & 4.7 \\
\hline
\end{tabular}

In comparison with well intensive dairy goats, average yield of 1.5-2.5 kg/day may not seems well, capability of milk production of Boer can be raised by presence of milk ancestry with high nutritional regime(Raats et al., 1983). advance in milch goats (Hayden et al., 1979). Sequential lactation also intensifies the amount of milk produced (Prakash et al., 1971). Milk production in the doe regarding multiple born kids are strongly affected by seasonal influence. As Boer are not selected for milk producing trait, it is just an extension of reproduction under natural conditions and varies with litter size and lactation number (N. H. Casey \& Van Niekerk, 1988).

Table.14: Milk analysis of Boer goats at GRS, Bandipur (NCRP, 2018)

\begin{tabular}{|l|l|l|l|l|l|l|l|}
\hline FAT\% & SNF\% & Density & Lactose\% & Solids\% & Protein\% & F. P & Conductivity \\
\hline 8.48 & 8.11 & 26.19 & 4.23 & 0.82 & 3.02 & -0.54 & 4.29 \\
\hline
\end{tabular}

The average daily gain (ADG) of kids is directly correlated to the milk production of dam with a preweaning ADG of $300 \mathrm{gm}$, the doe most yield up to 2.5 litres of milk per day. $4^{\text {th }}$ week of lactation must be the peak period of milk production. Though the doe produces sufficient milk to advance 2 kids, the supplementation of feedstuff to the doe with twin or triplets is decidedly prudent(Barry \& Godke, 1991).
Milk composition and quality are the attributes which determines the nutritive value which are affected by stage of lactation, parity, breed and season.

\section{Meat production performance:}

As the young Boer got tender and very tasty meat, it is raised for meat production. They must be marketed at a very young age to have better dressing percentage. The dressing percentage at specific ages is presented below:

Table.15: Dressed weight percentage of slaughtered Boer Goats (Barry \& Godke, 1991)

\begin{tabular}{ll}
\hline Age & Dressed Percentage \\
8-10 months & $48 \%$ \\
2 teeth & 505 \\
4 teeth & $52 \%$ \\
6 teeth & $54 \%$ \\
Full teeth placement & $56-60 \%$ \\
\hline
\end{tabular}


Other mutton breed has no higher dressing percentage for young animals. 28-43 kg live-mass weight is best merchantable weight for young goats. There is no satisfactory fat casing in the carcass of young goats weighing $<18 \mathrm{~kg}$ and is often differentiated counter to kids implies the meat of goat with no perpetual incisors. This arrangement has superiority carcasses with a thin coating of fat. Too little or too abundant fat or a weak configuration causes aninferiorcategorizing of the carcass(Godke, 1977). The Boer goat used as crossbreeding increases growth and meat characteristics in local goats. Boer meat has a sturdier savour than mutton due to its habit of grazing bushes and shrubs comprehending aromatic compounds. Meat becomes tough due to less amount of subcutaneous fat during cold shortening(Norman Henry Casey, 1983).

\section{Disease resistance performance:}

Statistics about resistance of disease on the Boer is comparatively less. Regardless of this, Boer are believed to be relatively disease resistant due to their grazing habit (Skinner, 1972).Better management practices of natural grazing lowers the dose to goats against internal parasites (Greyling, 1990).Habit of tree climbing helps them to be less susceptible to parasite infection occurred in the grass cover(Erasmus, 2000). Being fairly healthy breed, they are resistant to blue tongue, prussic acid poisoning, enterotoxaemia ( pulpy kidney Clostridium perfringes type-D ) and gall-sickness(Hugo, 1968) but kids development is strappingly retarded by internal parasite infection (Erasmus, 2000).During winter and spring Boer are subjected to bule tick infestations (Linognathus africanus) (Fourie et al., 1991). Due to being immune to tuberculosis benefit of utilizing goat milk is that this disease cannot be contracted by humans. It also cures erysipelas(rash) in small children and is prescribed to cure 'bawling babies'(Campbell, 1998). Higher cortisol production is maintained in Boer goat, a superior adrenal function. For the induction of several gluconeogenic enzymes that enables animals to survive stressful conditions, secretion of cortisol by the adrenal cortex is essential. CRF stimulates ACTH secretion form anterior pituitary as $\mathrm{CRF}$ is stimulated by the release of corticotropin-release factor (CRF) which is stimulated by stress. Glucocorticoids are secreted from the adrenal cortex promoted by ACTH and favour glucose production at the expense of glycolysis (Engelbrecht \& Swart, 2000). Cortisol production is high in Boer goat in stress condition partially explain the superiority of disease resistant and adaptation. Being a good browser, in the unavailability of shrubs, it prefers not to graze in the early morning when there is higher chance of contamination due to dew on grass. This resistance ability of Boer makes its reproductive life cycle of up to 10years and more(Barry \& Godke, 1991). Due to capability of drought resistance, tolerance of tannins, efficient fibre digestion, adaptation to various ambient temperature and lower water turnover rate, they become more disease resistance compared to other breeds and ruminants too( $\mathrm{Lu}, 2001)$.

\section{Kid mortality:}

Under extensive rearing the mortality seems relatively high. As kids born as single, twins, triplets and quadruplets, the mortality rate is $10.8 \%, 8.3 \%, 20.8 \%$ and $31.3 \%$ respectively (Erasmus et al., 1985). Kids born as triplets and quadruplets suffers the highest mortality (Els, 1995). Exposure to cold, milk shortage from doe, too small birth weight of kid are the important factors affecting kid mortality regardless of causes of mortalities in small stock (Olivier, 1980). Despite of these facts, cognisance should be taken of that other factors may influence eventual weaning rates. Predators like black-blacked jackal and lynx, stock thefts may contribute in kid losses(Erasmus, 2000). Out of 42 kids, 2 died (4.76\%) in a research conducted in Boer $50 \%$ in GRS, Bandipur(NCRP, 2017).Higher survival rate of kids was found which are born in wet season (Hailu et al., 2006). Male kids had lower survival rate than female kids as similar impacts due to litter size and sex of kid on survival(Browning $\mathrm{Jr} \&$ Leite-Browning, 2011).

\section{Grazing performance:}

Flexibility in harvesting forage and capability to survive under adversative scavenging conditions are the physiognomies of goat that set them apart from other livestock species (Lu \& Potchoiba, 1988). Being reported as browsers, their diet consists of $82 \%$ browse and $18 \%$ grass. Study in Namibia indicated that $74 \%$ leaves and $26 \%$ grass are consumed by Boer goats(Viljoen, 1980).Acceptance of goats towards bitterness plays asignificantrole to take full advantage of grazing capacity and in biological control of weeds as they do not dig out roots under harsh grazing conditions(Lu, 2001). Bush and shrub encroachment are creating detrimental impact on animal production on global range. One direct consequence can be exampled the deterioration of natural vegetation which results in decreased carrying capacity ultimately limiting red meat production (Erasmus, 2000). Grazing of goat lies in a wider spectrum of plants than other type of small stock and are inclined to forage from the top downwards from approximately equal to $160 \mathrm{~cm}$ to $10 \mathrm{~cm}$ (Aucamp \& Du Toit, 1980).Portulacaria afra, other shrubs and grasses are consumed in the ratio of 37:38:25 by Boer goats. This damages less to the extra sensitive 
ground layer vegetation including seedlings, young plants and crown plants (Stuart-Hill, 1987). Despite of being heavy eaters, feed conversion ratio of Boer crossbreeds as well as purebred Boers about 2.5-3.5 kg dry matter per weight gain. Goat's adaptive ability enable it to perform equally on grass-only diet and survived where browse had been absent from their diet (Mahmoud, 1978). Apart from browser, it is also a good walker and is able to withstand the deteriorated natural pasture and is also mentioned as a controller of bush encroachment as they do not get tangled in thorn, bushes and shrubs and need not be protected from rain and cold (Campbell, 1998). Boer are also popular for maintenance of landscape in forest areas because regardless of their diets they are less choosy (Erasmus, 2000).

\section{CONCULSION}

The growth performances and growth rate of Boer crossbreed was highly significant different than local and other crossbreeds of goats found in Nepal. Boer goats are able to gain diverse gratitude for outstanding body configuration, fast growing rate and good carcass quality. Grouping of breed standards and performance testing is likely to be the well approach for the effective selection and enhancements of Boer goats. Heavier body weight and faster growing rate are the most notable traits among all superior traits for production of meat. Because of their desirable traits they have successfully improved productive performances, hardiness, adaptability, fertility and disease tolerant of indigenous breeds through cross breeding. Prominent improvements consist birth weight, growth weight, weaning weight, breeding weight, mature kids, kidding rate and carcass quality. These goats possess characteristics including versatility, harvesting forage and ability to survive under adverse foraging conditions that set them apart from other livestock species. Boer are reported to have superior adrenal function and able to maintain higher cortisol production. Kidding rate and twinning percentage of Boer cross was also better than other breeds and mortality rate was also very nominal as compared to Khari. It is concluded that Boer goat may be the best substitute breed for crossbreeding with indigenous breeds in order to upsurge performances from the goat farming in Nepal. Continuous upgrading in genetic assortment, feeding technique and supervision arrangement may subsidize to even faster growing rate in Boer crosses in future.

\section{REFERENCES}

[1] Aucamp, A. J., \& Du Toit, P. F. (1980). The Boer ISSN: 2456-1878 goat in a grass-bush community. Boer Goat News, 1 , $17-25$.

[2] Barry, D. M., \& Godke, R. A. (1991). The Boer goat: the potential for cross breeding. Proceedings of the National Symposium on Goat Meat Production and Marketing, 180-189.

[3] Barry, D. M., \& Van Niekerk, C. H. (1990). Anaplasmosis in improved Boer goats in South Africa artificially infected with Anaplasma ovis. Small Ruminant Research, 3(2), 191-197.

[4] Belay, S., Gebru, G., Godifey, G., Brhane, M., Zenebe, M., Hagos, H., \& Teame, T. (2014). Reproductive performance of Abergelle goats and growth rate of their crosses with Boer goats. Livestock Research for Rural Development, 26(1).

[5] Bhattarai, N., Amatya Gorkhali, N., Kolakshyapati, M., \& Sapkota, S. (2019). Breeds and Breeding System of Indigenous and Crossbred Goats in Nepal. Goats (Capra) [Working Title], August. https://doi.org/10.5772/intechopen.82821

[6] Bhattarai, N., Kolachhapati, M., Devkota, N., Thakur, U., \& Neopane, S. (2017). ESTIMATION OF GENETIC PARAMETERS OF GROWTH TRAITS OF KHARI GOATS (Capra hircus L.) IN NAWALPARASI, NEPAL. International Journal of Livestock Research, January, 1. https://doi.org/10.5455/ijlr.20161218124223

[7] Browning Jr, R., \& Leite-Browning, M. L. (2011). Birth to weaning kid traits from a complete diallel of Boer, Kiko, and Spanish meat goat breeds semiintensively managed on humid subtropical pasture. Journal of Animal Science, 89(9), 2696-2707.

[8] Campbell, Q. P. (1984). development of a meat producing goat in South Africa. Proceedings of the 2nd World Congress on Sheep and Beef Cattle Breeding, 16-19 April 1984, Pretoria South Africa/Edited by JH Hofmeyr and EHH Meyer.

[9] Campbell, Q. P. (1998). The Boer goat-outstanding producer of red meat from low quality grazing. Boer Goat News. Boer Goat Breeders Assoc. South Africa, 45-52.

[10] Casey, N. H., \& Van Niekerk, W. A. (1988). The boer goat. I. Origin, adaptability, performance testing, reproduction and milk production. Small Ruminant Research, 1(3), 291-302. https://doi.org/10.1016/0921-4488(88)90056-9

[11] Casey, Norman Henry. (1983). Carcass and growth characteristics of four South African sheep breeds and the Boer goat. Universiteit van Pretoria.

[12] CBS, N. (2012). National population and housing census 2011. National Report.

[13] Coetzer, W. A., \& Van Niekerk, C. H. (1987). The 
effect of undernutrition on the occurrence of abortion and plasma progesterone levels in the improved boer goat. Proceedings of the IVth International Conference on Goats, 11, 1489-1490.

[14] Deribe, B., \& Taye, M. (2013). Growth performance and carcass characteristics of central highland goats in Sekota District, Ethiopia. Journal of Agricultural Advances, 2, 250-258.

[15] Els, J. F. (1995). Production analysis of a Boer goat flock in bush Savanna veld. Universiteit van Pretoria.

[16] Engelbrecht, Y., \& Swart, P. (2000). Adrenal function in Angora goats: a comparative study of adrenal steroidogenesis in Angora goats, Boer goats, and Merino sheep. Journal of Animal Science, 78(4), 1036-1046.

[17] Erasmus, J. A. (2000). Adaptation to various environments and resistance to disease of the improved Boer goat. Small Ruminant Research, 36(2), 179-187. https://doi.org/10.1016/S09214488(99)00162-5

[18] Erasmus, J. A., Fourie, A. J., \& Venter, J. J. (1985). Influence of age on reproductive performance of the improved Boer goat doe. South African Journal of Animal Science, 15(1), 5-7.

[19]Feed, U. S., \& Council, G. (1997). Mycotoxins in feed. World Grain, 15, 30-31.

[20] Fourie, L. J., Novellie, P. A., Williams, E. J., \& Horak, I. G. (1991). Parasites of domestic and wild animals in South Africa. XXVI. The mosaic of ixodid tick infestations on birds and mammals in the Mountain Zebra National Park.

[21] Godke, R. A. (1977). THE BOER GOAT Milk Production Growth. 6.

[22] Greyling, J. P. C. (1990). Sexual activity of the Boer goat. Boer Goat News, 9, 51-53.

[23] Greyling, J. P. C. (2000). Reproduction traits in the Boer goat doe. Small Ruminant Research, 36(2), 171-177.

[24] Greyling, J. P. C., \& Van Niekerk, C. H. (1986). Synchronization of oestrus in the Boer goat doe: Dose effect of prostaglandin in the double injection regime. South African Journal of Animal Science, 16(3), 146-150.

[25] Hailu, D., Mieso, G., Nigatu, A., Fufa, D., \& Gamada, D. (2006). The effect of environmental factors on preweaning survival rate of Borana and Arsi-Bale kids. Small Ruminant Research, 66(1-3), 291-294.

[26] Hayden, T. J., Thomas, C. R., \& Forsyth, I. A. (1979). Effect of number of young born (litter size) on milk yield of goats: role for placental lactogen. Journal of Dairy Science, 62(1), 53-57.
[27]Hugo, W. J. (1968). small stock industry in South Africa.

[28]Lu, C. D. (2001). Boer Goat Production: Progress and Perspective. Proceedings of International Conference on Boer Goats. October 20-24, 2001., 111. http://www.adga.org/breedinfo.html

[29]Lu, C. D., \& Potchoiba, M. J. (1988). Milk feeding and weaning of goat kids-A review. Small Ruminant Research, 1(2), 105-112.

[30] Mahmoud, M. (1978). Potentialities for improving range management in mediterranean coastal desert of Egypt. Proc. First Int. Rangeland Congress, 45-47.

[31] McDowell, R. E. (1972). Improvement of livestock production in warm climates. Improvement of Livestock Production in Warm Climates.

[32] Mustefa, A., Gizaw, S., Banerjee, S., Abebe, A., Taye, M., Areaya, A., \& Besufekad, S. (2019). Growth performance of Boer goats and their F1 and F2 crosses and backcrosses with Central Highland goats in Ethiopia. Livestock Research for Rural Development, 31(6).

[33] NCRP. (2014). Annual Report 2070-71 (2013-14). 71.

[34] NCRP. (2017). Annual Report 2073-74 (2016-17). 4. [35] NCRP. (2018). Annual Report 2074-75 (2017-18). 5. [36] NCRP. (2019). Annual report 2075-76 (2018-19). 6.

[37] Neopane, S. P., \& Sainju, A. P. (1995). Performance of Kiko crossbred goats in the midhills of Nepal. Promotion of Animal Production through Research and Development, 100-104.

[38] Neupane, N., Neupane, H., \& Dhital, B. (2018). A Socioeconomic View of Status And Prospects of Goat Farming in Rural Areas of Nepal. Journal of the Institute of Agriculture and Animal Science, 35(1), 18. https://doi.org/10.3126/jiaas.v35i1.22508

[39] Nugroho, T., Kustiyani, C., Ratriyanto, A., Widyas, N., \& Prastowo, S. (2019). Reproductive Rate Performance of Boer Goat and Its F1 Cross in Indonesia. IOP Conference Series: Earth and Environmental Science, 334(1), 8-12. https://doi.org/10.1088/1755-1315/334/1/012008

[40] Olivier, J. J. (1980). The influence of objective and subjective selection methods and environmental conditions on production and reproduction characteristics of Merino sheep at the Carnarvon experimental farm. M. Sc.(Agric.) Thesis. University of Stellenbosch.

[41] Panday, S. B. (2008). Boer Goat ( Capra hircus ): an Alternative Breed to Increase Meat Production in Nepal: A Review. August, 311-319.

[42] Prakash, C., Acharya, R. M., \& Dhillon, J. S. (1971). Sources of variation in milk production in Beetal 
goats. Indian Journal of Animal Sciences.

[43] Raats, J. G., Wilke, P. I., \& Du Toit, J. E. J. (1983). The effect of age and litter size on milk production in Boer goat ewes. South African Journal of Animal Science, 13(4), 240-243.

[44] Rasali, D. P., \& Khanal, R. C. (2002). Comparative Performance of Indigenous Crossbreds of Goats at Lumle Farm, Nepal. 4, 129-134.

[45] Sapkota, S., Kolakshyapati, M., Gairhe, S., Upadhyay, N., \& Acharya, Y. (2016). Boer Goat Production Performance, Constraints and Opportunities in Nepal Monitoring and Evaluation Division 123 , Planning Division 45 NARC. Imperial Journal of Interdisciplinary Research (IJIR, 2(12), 491-495. https://doi.org/10.5281/zenodo.1183837

[46] Sciences, A. (2017). Nepalese Journal of Agricultural. 15(September), 35-42.

[47] Secretary, J., \& Division, P. (2015). Nepal Portfolio Performance Review ( NPPR ) Ministry of Agricultural Development ( $M o A D$ ) Organization of Presentation.

[48] Shelton, M. (1978). Reproduction and breeding of goats. Journal of Dairy Science, 61(7), 994-1010.

[49] Shkolnik, A., \& Choshniak, I. (1985). Physiological responses and productivity of goats.

[50] Skinner, J. D. (1972). Utilisation of the Boer goat for intensive animal production. Tropical Animal Health and Production, 4(2), 120-128.

[51] Stuart-Hill, G. C. (1987). Refinement of a model describing forage production, animal production and profitability as a function of bush density in the false thornveld of the eastern cape. Journal of the Grassland Society of Southern Africa, 4(1), 18-24.

[52] Upreti, C. R., \& Mahato, P. S. (1995). Study on the genetic and phenotypic characteristics of indigenous goat breed (Sinhal).

[53] Van der Westhuysen, J. M. (1979). The oestrus response and changes in plasma progesterone concentrations of Angora and Boergoat does following injection of GnRh analogue. South African Journal of Animal Science, 9(1), 17-19.

[54] Viljoen, B. (1980). You've got to get a goat or two. Farmer's Weekly, 11. 